\title{
Long-time Effects from Kosovo, Little Ado About Bosnia-Herzegovina
}

\author{
Michael Daxner and Sarah Riese*
}

\begin{abstract}
This article inquires into the geopolitical implications of current and recent developments in the Balkans. Our main hypotheses are that the Balkans are a "laboratory" for blueprints of societies and statebuilding after interventions, and that Kosovo is something like the independent non-sovereign state resulting from such interventions. We find Kosovo's declaration of independence to be of geopolitical significance, as it has weakened the position of the UN Security Council as well as the principle of sovereignty against supremacy of independence under the support of powerful actors. Recent developments in Bosnia by contrast have little geopolitical repercussions, other than providing a "testing ground" for international and particularly EU peacebuilding strategies.
\end{abstract}

Keywords: Intervention, peacebuilding, South Eastern Europe, geopolitics, European foreign and security policy Intervention, Friedensstiftung, Südosteuropa, Geopolitik, Europäische Außen- und Sicherheitspolitik

\section{Introduction ${ }^{1}$}

$\mathrm{O}$ ur main hypotheses are that the Balkans are a "laboratory" for blueprints of societies and statebuilding after interventions, and that Kosovo is something like the independent non-sovereign state as a result from such interventions. While there are many lessons to be learned from the interventions in the region since 1991, the impact of both the recent development and the perspectives for the future of both countries are all but clear. There might even be a kind of standstill because of too many idiosyncratic antagonisms among the main players and agencies. However, a few issues are ripe to be tackled with more stringent determination than in the past: two of the reasons are obviously the Advisory Opinion on Kosovo by the International Court of Justice (ICJ), of July 2010, and the upcoming demotion of the Office of the High Representative (OHR) in Bosnia-Herzegovina $(\mathrm{BiH})$. But there is a wider context, provoked by the question of real or imaginary geopolitics.

* Michael Daxner is professor of sociology at the University of Oldenburg, and leads a research project on the intervention impact in Afghanistan within the Collaborative Research Center on Governance in Areas of Limited Statehood at Free University Berlin (SFB 700). He also was the responsible Officer for UNMIK for Education and Higher Education in Kosovo until 2002, where he developed a few theoretical aspects on education or public health (Daxner 2003). Currently he works on conflict theory, state building and the anthropology of interventions and ethnography in conflict zones. Kosovo was the cradle of a new research field on the culture of interventions (www.culturesofintervention.org), reflected in his work for the Collaborative Research Center on Governance in Areas of Limited Statehood, at the Free University of Berlin (SFB 700). Sarah Riese is PhD student in political science at Free University Berlin, research associate on the project of Post-War Democratic Transitions led by Christoph Zuercher (Ottawa) and member of the research network on Cultures of Intervention. Her PhD thesis focuses on peacebuilding in Bosnia and Herzegovina and the interaction of interveners and $\mathrm{BiH}$ political elites.

1 A recent discussion at the CEDS in Paris circled around the question if there were any geopolitical aspects of the present situation in the Balkans. This French academy has produced interesting contributions regarding the position of the United States (Chaigneau 2010) and the enlargement of the European Union with effects on the Balkans (Gruber 2010). Michael Daxner concentrated on Kosovo, because he was able to present consistent hypotheses on the future development, especially after the International Court's opinion of July 2010 . Bosnia-Herzegovina $(\mathrm{BiH})$ played a marginal role and will be dealt with separately.

\section{The Balkans in Context: The end of the Cold War, EU enlargement, and changing norms of sovereignty}

For Europe and the world, the postwar narrative has changed dramatically after 1989. Europe is the theatre where this change has been staged. The dual hegemony of two systems of political civilization had come to an end, and for a moment it seemed that there would be a window opened for sustainable international peace and development. Some even spoke of the 'end of history' and claimed that liberal democracy and capitalist market economy would unify the global political landscape. We know today that this was too early spoken, and for many reasons the world has changed into a less transparent complexity. We leave it to your judgment whether this new constellation has become more peaceful, less violent, more prosperous and promising. We guess that the scientific community and the public at large are familiar with the challenges of the new era; many of these challenges became obvious in the Balkans during the 1990s and the first decade of the 21st century. While some of the most pressing problems, such as climate change, have never been at the core of the Balkan conflicts, some other problems have become almost paradigmatic in this region. We shall concentrate on these problems without neglecting their interface with many more challenges:

- Geopolitics would not be a problem of discourse in political science, if the precedent of Kosovo independence had not sent invisible shock-waves to all regions on earth. Globalization is replacing old geopolitical patterns. Geopolitics has become an outdated and even pejorative term, given the complex situation under globalization. Moreover, the apparent position of the United States as the only remaining superpower after 1989 soon has turned out to be transitional - the weaknesses of unilateral supremacy are evident, and new players, some of them with influence on all continents, are emerging. Under this assumption, Kosovo has some geopolitical significance, $\mathrm{BiH}$ has not.

- Europe has begun to unite under the format of the European Union, and the Balkans turned out to be a pivotal sector of 
virtual, and belated, real enlargement strategies, changing both the region and the EU. EU-Europe is facing other notions of "Europe(s)" - not without conflicts. This is very important insofar as the accession towards the EU-Europe does not automatically converge with the perception of the citizens to 'belong' to the new Europe.

- New wars and asymmetric violent conflicts have replaced traditional wars among nation states. Sovereignty and the Westphalia model are becoming eroded and partially replaced by supranational and local conventions. International law and contracts are still in a phase of transition. The Balkans are not a region with explicit mezzanine rulers, but there have been quite a few strongmen and actors of violence, to consider the alternatives to the very hegemonic scope as recently discussed (Crawford 2010). If the irony is permitted, some of the main actors behaved like the mezzanine of mezzanine rule during the violent conflicts and thereafter.

- If we draw a baseline in 1991, we would find no coherent European security architecture, while NATO had already lost the strategic and political leadership in orienting its members and potential allies. Before Dayton 1995, all activities considering "European security interests" by CFSP (Common Foreign and Security Policy) (Heider 2010b) appear to be poorly coordinated and targeted. Economically, the question was after 1989, in which way an integration of the CEE-states under the umbrella of the Brussels paradigms of market and trade unification could be realized, while the question of political unification was grossly neglected. We see in this one of the main causes for the conflict in the nineties. (Only today, under the crisis of the Euro, the political union has become a real issue again).

These four problem zones shall frame the argument in our considerations.

\section{Geopolitics and the Balkans after 1989: The break-up of Yugoslavia and the hazards of recognition}

While Poland, Czechoslovakia (later Czech and Slovak Republics) and Hungary became nation states again, the Baltic countries emancipated themselves from Moscow rule as relatively consistent ethnic people states with a certain tradition of a nation state legacy; this was certainly less true for Yugoslavia, and at least ambiguous in the rest of SEE (Romania, Bulgaria, Albania).

Yugoslavia (originally the Federal Republic of Yugoslavia, FRY) was rapidly dismembering - or dismembered with the help of some European powers? - and thus complicating the situation. If we want to apply geopolitical considerations in our discourse, then we must also look at the United States with regard to the new states in CEE. Most of these states are invisibly divided into structures of European allegiance and an inclination to bind them tighter to the U.S. (e.g., as members of several coalitions of the willing, or joining NATO at the first occasion, regarding the alliance as U.S.-dominated; there is a strong "ambivalence" towards Western/European/traditional national values, which is often oriented by U.S. diasporas).

The baseline was characterized by little resistance against the erosion of the FRY. There was much sympathy in the West for the statebuilding efforts of Croatia and Slovenia, mainly due to the obvious dictatorship under Milosevic; this regime seemed to justify the new doctrines of humanitarian intervention and human security (1995-2000). But due to this the future of Serbia was grossly neglected, as if the status of culprit should be preserved in order to fortify the new statebuilding efforts. There was too little imagination about the detrimental effect on six or eight successor states instead of one well-structured nation state, but that is history.

Another element is even better buried in the caves of collective memory. What might have been the interest of the U.S. to engage itself at all in a conflict that is mirroring in a strange way the 19th century statebuilding conflicts? It seems to be over-simplified, but there is one motive of high plausibility. Until the Kosovo-intervention in 1999, the U.S. did not have any military base in Eastern Europe, and the NATO bases in Greece and Turkey were charged with conflict between these two countries ${ }^{2}$. Camp Bondsteel in Kosovo has been, indeed, the first base, and was symbolically highly important until the U.S. attained their major bases in Romania (Pfaff 2010).

The anti-Serbian feelings, which were in fact belated anti-Soviet/ Socialist resentments, may also play a role, while the Croats got more support in the West, despite the right-wing populism and political legacy in parts of their national movements. Note well that neither Slovenia nor Croatia had a significant history of statehood. Leaving Serbia out of the new arrangements turned out be a massive mistake. Perhaps it is too harsh a judgment if we accept that the policy of recognition towards Croatia and Slovenia involuntarily added to the ethnicization of the regional conflicts, simply by aiming at "nation-states" and with the foundations of this model not having been advanced enough.

One other aspect may be the revival of political structures that had been geopolitical before the outbreak of World War I. Never since had the unfinished structures and historical framing been sufficiently discussed and 'politicized'. We call the region one of unfinished prospects. In political science, the anecdotic narratives do not play the big role as in everyday discourse. But on the level of everyday life, the closeness to the unfinished projects of emancipation and enlightenment more than one hundred years ago is resurfacing at the lightest provocation.

\section{Geopolitics and the Balkans in 2010: The role of the EU, and the geopolitical impact of Kosovo's independence}

Let us break up this sketch and highlight the present constellation. If we look upon the Balkans from atop a hill, we find one paradigm that is shaping all interpretation. The entire

2 The ranking political advisor to UNMIK, Oleg Levitin, had pointed out this argument very early in the mission. 
region is an accession space for the European Union. Slovenia is a full member; Croatia is under fairly advanced membership negotiations. Macedonia and Montenegro have been given promises and expectations. But $\mathrm{BiH}$ is far away from concrete membership negotiations, and so is Kosovo. The case is more complex with Serbia. (We shall leave out Albania here.)

There is an assumption that globalization means Europeanization for Europe. This would need a very specific in-depth discussion, but roughly speaking it is the attempt to unite Europe under the terms of a union to be, inevitably deemed to become a political union or to fail. If we project this assumption to geopolitics, then it would be clear that the EU has to accomplish this unification, probably with the inclusion of Turkey and perhaps Ukraine and Belarus, in order to become a real global player again.

Another variable in this context is the shift of U.S. interests towards the new big players such as China, India and Brazil, and the reduced importance of transatlantic agendas. However, Europe should not be seen as qualité or quantité négligeable. But the overall erosion of American unilateralism plays a certain part in our considerations. While the EU is currently not in a very good shape, we hold this due to inevitable diachronic developments and not a question of principle.

A third component of our assessment is the revamped nationalism in most member states of the EU and, more so, in the Balkan states. This fact is increasing the difficulties for nation-states to become members of the supranational systems. The explanation, plausible immediately after 1989 for the rest of the East European states, but no longer acceptable as real element of polity, and now rather symbolic, is that because of the long-term domination of these states by the Soviet Union, there was a desire to become a "nation again" for each of the countries. But this nationalism is often unfounded by recent history and needs a revitalization of anachronistic mythology in the Yugoslav republics and provinces. On the other side, people in the Balkans observe keenly the growing fatigue de democracie in Western Europe and amidst EU members. They nurture the perception that it is less the peace-project or the political union that should attract them, but the advantages of economic and military enhancement. In the financial crisis, even this argument loses in glamour though.

For some reasons, the Kosovo impact on international politics seems to be more significant at the moment than the $\mathrm{BiH}$ issue. In the case of Kosovo, a bundle of particular interests has succeeded to encourage a declaration of independence that created a new state. While this is nothing new in the region, it is entirely new from the point of view that the country was in 2008 still a protectorate of the United Nations under SecC. Resolution 1244 of 10 June 1999. Any autonomy, selfgovernment and attempts to render independent Kosovo as a political entity had been conditioned by the interveners and by the supranational instances after 1999. Furthermore, the findings of the International Court of Justice on the compatibility with international law of the declaration of Independence itself did set a precedent for future emerging states despite this having been immediately denied by most of the international players in the game, notably the U.S.
Our assumption before the ICJ's advisory opinion of 22nd July 2010 (vote 10:4) ${ }^{3}$ had been that the declaration of independence of 17th February 2008 was the product of the majority of the Kosovar people's will plus the support by international actors in favor of this statebuilding. It was clearly a popular decision that was not in line with the wording and spirit of UN SecC Resolution 1244, and despite the fact that a majority of Security Council members at the time had an inclination towards this secession of Kosovo from the FRY (and later Serbia) ${ }^{4}$, Kosovo was a society with political stamina overruling insufficient ruling by international law (for other reasons, mainly my own experience in UNMIK, I (Michael Daxner) had much earlier the idea that there would have been a resolution of the conflict on the basis of substantial autonomy within Serbia or a true independence supported by international law, but the windows of opportunity for both solutions had been closed much earlier). Had the UN Security Council altered the resolution before the formal secession of 2008 , the situation would have been very different. Thus, it is no surprise that among the many statements presented to the court, those who argued in favor of independence gave political legitimacy to the act, while those opposed mainly argued on the grounds of Resolution 1244 and their interpretation of international law. The result is clear: the court simply said that the declaration was not in violation of international law, and the further question of the recognition of the Republic of Kosova was a political issue, implicitly not one of legal foundations. Understandably, the Serbian argument, when seeking the opinion of the court, was exactly the opposite of this outcome. The main arguments, brought forth sometimes with much sophistication, were on the side of supporters of the new state and that it will play an important role for regional peace and security and - legally more interesting - that Serbia has lost its right over Kosovo due to its violations of human rights and improper governance. This seems to be a normative reflection of the fundamental change in international institutions: now, the ethical imperative of the Responsibility to Protect, of Human Security, and the framing by Human Rights dictate the legitimacy of interventions - and of new states emerging from people's insurgence. But it is not as easy as that. We still have the need to accept and recognize an instance that is able to decide if a nation, or a people, is free to create a state by replacing a previous one. In the case of Kosovo, UNMIK has replaced the anteceding state (FRY, Serbia) by just virtually opening the door for another state. This was not intended, but could be anticipated. It is a striking argument: Serbia has "lost the right" to govern a mistreated part of its people and territory. Thus, the statebuilding appears like a sanction on principles violated by the rulers of the state. Implicitly, the statebuilding according to this argument is a kind of revenge from the formerly oppressed - and certain

3 Documents and references: http//: icj-cij.org.docket/files/141/16010/pdf viewed 1/11/2011. Other references: en.wikipedia.org/wiki/International Court_of_Justice advisory opinion on Kosovo's declaration of independence, viewed 1/8/2011. The General Assembly had voted 77 for and 6 against the demand of an advisory opinion by the court, with 74 abstentions. Among the abstentions were practically all EU-members. The U.S. and Albania were the most significant no-votes.

4 The wording at the UN Security Council in Spring 1999 was under the threat of veto by Russia because of the expectation that a UN-granted independence and the creation of a sovereign state would be a precedent notwithstanding the U.S.-claim that Kosovo was an 'exceptional' case. 
impunity against the likely violations by these former victims who are now determining their own fate. By its normative and value-borne morals, this argument is good for any precedent in the future - subject to recognition by those powers who will accept or deny such a state its vigor to survive.

The representative for the new state did also bring the argument of the "will of the people" that would make the decision to secede irreversible from Serbia. On the side of the opponents to independence, the main arguments were the principles of territorial integrity of the Republic of Serbia, of this state's sovereignty, and strong reference to the wording of SecC Resolution 1244. Of course, this group of opponents used the plausible argument of precedent as a strong tool against the lawfulness of the declaration.

Our readers will forgive us for not going into the very sophisticated details of the court procedures and most of the reactions. We are interested in the geopolitical frame set by the reality in Kosovo and the interpretation of the Court's opinion, which is not legally binding to anyone. The main effects of the ruling are the following: If not legally, the opinion has a strong psychological and pragmatic effect on countries or peoples seeking secession from their respective state. In the case of Kosovo, the internal structure of the new state and its position within a community of states - regional and international - sets a precedent insofar, as this new state seems to be a blueprint for post-intervention statebuilding. The declaration of independence has weakened the position of the UN Security Council. It has also weakened the principle of sovereignty against supremacy of independence under the support of powerful actors.

Some consequences from these effects can be described as follows:

- If international law is not against a declaration of independence forced by unofficial or weakly legitimated governing bodies, real independence relies on the assistance or even indirect rule by strong supporters of the new state. This is encouraging separatist movements wherever - or disappointing them, if recognition and support are denied. Each of these movements may have better or worse arguments for secession, but the process of gaining effective independence would fall short of procedures embedded in international law or of conventions that are binding for all actors.

- Kosovo is not a nation-state that would show all the ingredients for such a state being able to sufficiently and sustainably deliver all elements of good governance. It is a specific case of good enough governance as accepted by those who are decided to keep the new state alive by material and informal support. Neither the principles of liberal statebuilding (ideal-typical as represented by James Dobbins (Dobbins et al. 2008) nor of republican peacebuilding (ideal-typical as represented by Michael Barnett (Barnett 2006) have been adopted as a result from humanitarian intervention and peacekeeping. However, with the help and continuous external infusion of money and power, the experiment of founding a state and only afterwards constituting its real statehood may - or may not - succeed. Why did we call the model of Kosovo a blueprint for post-intervention statebuilding? A few, but not all ingredients of an intervention are considered to be enough as to accept an act of secession and statebuilding, which had never been the explicit aim of the intervention. Since some of the successful aspects are relevant, e.g. the decline of ethnic and politically motivated violence, the declaration of independence did meet a minimalist strategy under the argument that it is better than no development at all. Consequences had not been considered, e.g. what will be the future of the North of Kosovo, populated mainly by Serbs, or what will be the future reality of conditional independence in the sense of the Ahtisaari peace accord, or what might be the grounds for any accession to the EU under unclear delineation between UNMIK, EULEX and other forces on the ground (Daxner 2010). The minimalist outcome may be a solution for imperfect 'fluid stability' in post-intervention constellations. But we also find a new kind of suzerainty that was formerly attributed to the Serbian rule over Kosovo, and that is now, under different terms, enacted by the EU.

- The UN is weakened, because politically it is rather unclear how the UN Security Council can come down from Resolution 1244 without any key-player losing either face or influence. In fact, a state has been created that cannot become a member of the UN. But this state has been promised a European future by major speakers from EU member states, not least Germany. Since we have never been staunch advocates for exaggerated notions of sovereignty, we are not so troubled by the fact that Kosovo is far from sovereignty in terms of a factual capacity for foreign relations and international reciprocity. But we cannot imagine how the future of a state will be if it continues to be fully dependent on external input.

Indirectly, UNMIK has fostered statebuilding where it meant to do peacebuilding. In the beginning of the mandate (1999/2000), UNMIK's strategy was peacekeeping through administration, i.e. focusing on the elements of rule of law and security in good governance. Security was more or less well delivered - the rule of law was lagging behind in most sectors. The next phase, after 2001, was under the motive of peacebuilding through development, clearly aiming at the welfare aspect of good governance and the development of statehood. It was certainly a weak and controversial statehood within a state (UNMIK) and within another state (Serbia) and without a state (Kosovo). The social dynamics in the relation between the interveners and the intervened shaped a change in society that fell apart from the development of the institutions that were set by UNMIK in order to fortify statehood and prepare the ground for a kind of expectation at the end of which a real state would emerge, but with no clue how to hatch it.

There is a question of global interest. The UN had set almost unprecedented power for the UNMIK mission and it's Special Representative of the Secretary General. UNMIK was effectively the government, and never has been stripped of all qualities of this function. But how to be a government in a state that is no real state or belongs to another state or is on the way to a third status? If the intervention was a success, this is only partly due to the efforts of and effects from UNMIK, likewise of KFOR and 
OSCE. But why it was a partial success is less clear than why it failed in many respects. "Lessons Learned" by Brahimi was a guidebook in the beginning, but lessons learned from Kosovo are more important. It is of global interest how the UN should reform in order to cope with missions like Kosovo and how it should coordinate with other institutional partners (Stromseth 2006, Tolbert 2006). The precedent is unlikely to be repeated on the level of UN missions with so much power and so little guidance in using it.

Don't misunderstand the authors' position. From experience and theory, we are not against independence for Kosovo. But we can see that arguments like the ones from Vetevendosje (Albin Kurti et al.) will gain ground, if governance does not stabilize and meet the expectations of the people in the rule of law, in social welfare and education, and in the state's security. On the other side, it is not unlikely that the country will glide down the slope towards a really failed state, which may need massive rescue operations and even interventions beyond a certain point of social and cultural erosion. Our argument is that the problems of the new state could be declared as purely European or even regional, i.e. far from extended geopolitical considerations. In such a case, massive and robust support would lead this state into multilateral agreements on transparent borders and labor exchange and the recognition of property titles and of academic degrees, etc., but without starting to solve the biggest problems. This would require a better coordinated European foreign policy or, in the case of the region, domestic politics for the EU.

Much of the terrible mess in and about Kosovo is also caused by the failure to install a sustainable and transparent protectorate policy under UNMIK with a clear roadmap to hand over most responsibilities to the EU, and a consequential retreat of KFOR. This would require flexibility in the UN Security Council, and there we are at square one.

One of the arguments in favor of our initial hypothesis is that Kosovo may serve as blueprint for states that are released into good enough governance, just as a realpolitik instead of valuebased pragmatism. The latter would, in the case of Kosovo, but also in other societies of intervention, like Afghanistan, need more and not less international commitment to development and the building of institutions for all layers of good governanceand not just raisin-picking of the least expensive or least controversial at home. If democracy, human rights and a sustainable agreement will all neighbors in the region are no longer the explicit reasons for upholding the conditioning of independence, then the question is why the state is not released into full independence, including its unavoidable failure. Or does this present another way back to square one?

\section{Bosnia: A testing ground with little geopolitical implications}

The case of Bosnia and Herzegovina $(\mathrm{BiH})$ is also complex, but in many respects further from geopolitics than Kosovo. Compared to other cases of post-conflict intervention, $\mathrm{BiH}$ has received a lot of attention primarily due to its geographic location (Zürcher et al. 2009). However, external actors had little strategic interest in $\mathrm{BiH}$. Rather, it appears that particularly for the EU, BiH was and continues to be a problem that can neither be solved nor ignored.

The intervention in $\mathrm{BiH}$ marked a turning point from the more limited missions in the early nineties that focused on securing an absence of violence and organizing post-war elections, to more comprehensive attempts at transforming state and society. In that sense, BiH turned into a testing ground and a blue-print particularly for the transitional administrations in Kosovo and East Timor (Chandler 1999, Džihić 2009), also strongly based on a value-oriented legitimacy as is typical for humanitarian interventions.

In one major aspect, statebuilding under the terms of the Dayton Agreement and before shows a global problem: the strong weight given to ethnicity tends to lead in a direction where conflicts prove to be more difficult to regulate than before. And it proves highly problematic that the peacekeeping agreement of Dayton still serves in lieu of a constitution.

In $\mathrm{BiH}$, we can observe some negative effects from a poorly considered society of intervention. The "cantonization" (Cutilheiro-Plan) has narrowed conflict resolution to ethnic categories, where many social, religious, legal, cultural and historical roots of the conflict and neighboring states' interests had played a role preparing for conflict during long periods of the FRY. The international presence in the country and uneven authority in almost any agency at different times has led towards a mindset of resignation among the people that is also existent for most of the citizens of the new state.

$\mathrm{BiH}$ as a laboratory for peacebuilding may be an imperfect description, because the setting of the experiments lacked sufficient correspondence between the aims and the means (Heider 2010a). Peacebuilding in $\mathrm{BiH}$ was initially planned along the lines of earlier interventions such as Cambodia (Chesterman 2003, p. 79, Zaum 2007, p. 85) or in some ways Mozambique and Namibia (Zürcher et al. 2009). Intervention was to be short and centered on securing an absence of violence and organizing post-war elections to facilitate the creation of new state institutions and provide a basis for the withdrawal of the intervening forces. This approach soon proved unfeasible, resulting in substantially increased powers for the Office of the High Representative (OHR) in December 1997 (the "Bonn Powers") that essentially turned $\mathrm{BiH}$ into a quasi-protectorate (Evenson 2009). This has been described as marking the beginning of a new era of interventions (Chandler 1999, Džihić 2009) and in many ways a blueprint for later missions. Because $\mathrm{BiH}$ was a laboratory for new modes of intervention, postconflict peacebuilding, possibly even more than elsewhere, is to this day characterized by ad hoc adaptation to perceived new problems, and even more than elsewhere the interveners appear to have troubles to define an exit strategy and an end point to intervention. Since 2006 various attempts have been made to close the Office of the High Representative and hand it over to a reinforced EU presence, moving from deadlines to certain objectives and conditions to be met - and still no clear strategy at all (ICG 2011). 
The difficulties of transitioning from OHR to an EU "domain" appear to be rooted in a lack of a common strategy among those countries that comprise the PIC (Peace Implementation Council) Steering Board, concerning, in a lack of a clear EU strategy, what transition to strive for. The PIC Steering Board countries appear to differ in their assessments of the political situation in $\mathrm{BiH}$ and the question of whether $\mathrm{BiH}$ can govern itself independently (particularly the US, the UK and Turkey fear that this is not the case, see ICG 2011), as well as with respect to the role that $\mathrm{OHR}$ still should or can play in intervening in $\mathrm{BiH}$ politics (ICG 2011, Tirak 2010).

This unclear scenario is more complex as we find some incoherent international approaches on different timelines. There may be an attempt to sort out differences between the EU and the U.S.; there is certainly a link between Russia's position towards Kosovo and its policies on $\mathrm{BiH}$; there are some indicators about Turkey's increased efforts to become a more relevant player in the region; there are agencies that do not represent official policies, but are far from being apolitical in their strategies and tactics, such as Islamic appeals from various origins (Iran, Emirates etc.). These approaches are clearly not coordinated by any authority or common interest. The EU itself is acting in some incoherent way, such as using $\mathrm{BiH}$ (continuously) for attempts of creating an EU foreign policy, and testing EU peacebuilding tools, though with little coherent strategy (Balfour and Bieber 2010, Bassuener and Weber 2010, ICG 2011, Starčević-Srkalovi`2010).

The involvement of the EU in $\mathrm{BiH}$ has increased since 2000 and mirrors international engagement in general in that $\mathrm{BiH}$ has formed the testing ground for attempts at fostering an EU foreign policy and a distinctly European approach to peacebuilding. The shift towards EU peacebuilding went along with a shift in focus from implementing Dayton, to moving towards EU membership. Accordingly, two very different and often contradictory international approaches have co-existed simultaneously in Bosnia in the past few years. One is the more traditional "peacebuilding" approach that relied heavily on imposing reform, the other is peacebuilding by building EU member states, using the EU perspective as an incentive for $\mathrm{BiH}$ politicians to implement reforms themselves. While this approach is strictly speaking not about peacebuilding but EU accession, it is very much related to the aims of peacebuilding. The EU wants one partner to talk to in $\mathrm{BiH}$ and needs the state to implement laws and provisions to align with EU criteria. The focus of EU engagement hence is on strengthening the central state at the expense of other entities (Fagan 2010, p. 84).

The peacebuilding approach requires international authority in $\mathrm{BiH}$, while the EU approach requires that Bosnia is able to govern itself. The EU has found itself on both sides of the divide in past years. The disparate EU approaches and EU bodies in Bosnia are to be united under one roof now according to the treaty of Lisbon (though when we were in BiH in Spring 2010 nobody knew how this process would be organized and where it would lead to).

The "building memberstates" approach so far has shown some, though limited success. The idea is that the distant hope of EU accession will suffice as an incentive for $\mathrm{BiH}$ authorities to implement changes themselves. This happens by breaking large political questions down into long lists of small "technical" requirements (we call this "peacebuilding by ticking boxes"). This has worked for some issues where the process and its outcome were relatively clear and tangible such as the visa-liberalization process, and it is helpful for issues that have become more politicized than they should be. Other issues however do require political debate - but there is no solid public space within which such political negotiations and deliberations can take place. We regard this fact as a major impediment to sustainable peacebuilding. In $\mathrm{BiH}$, on the other hand, we can observe some negative effects from a poorly considered society of intervention, such as the above mentioned "cantonization".

When we said that there is a partial "Yugo-nostalgia", this is almost generic. There are quite a few reasons, some of them political, some of them cultural, but all of them packed with an unfinished past, recent and ancient. A benevolent interpretation of the efforts to quick accession of the entire region may be that the EU tries to undo the diverse reasons for the continuous fragmentation by building small and unstable states. This is not only a noble motive, but also another type of precedent, i.e. the building of true "union": The successful unification of a continent under one roof would be geopolitical, indeed.

Let us conclude. The Balkans never had been a sphere of interest on a very large scale, but was always a source of concern for European powers; the national developments gained in confrontational and conflicting capacities after the Crimean War and did not really come to terms with the rest of Europe after the First World War. The FRY was a geopolitical player for a while, when Tito was a leader for the Nonaligned Movement. The dissolution of the FRY after 1989 has been a collateral event of mixed consequences. Certainly the violence and ruptures by the wars after 1991 and the intervention of 1999 in Kosovo set a new and unprecedented disillusioning about the expected peace dividend of 1989. Many argue that the slow statebuilding of the successor states of the FRY remind us of the leftovers from the unsolved problems one hundred years ago. We do not think that this is entirely true, but it fits as a metaphor. One recent effect is that there are new borders in the case of Kosovo, but any other correction of new borders is being officially excluded from policies. More disquieting on a global stage is the Balkans as testing ground for the new Europe to attain its continental consistency and coherence. In other words, Europe failed to prove its political cohesion besides its economic power. At the same time, $\mathrm{BiH}$ and Kosovo are an open field for Islamic resurfacing and other activities off statehood. One could call this the local face of the global medal. Thus, the interventions only partially served their purpose; the conflicts they have produced - in BiH after 1995, in Kosovo after 1999 - may encourage more sophisticated thoughts about humanitarian interventions and peacekeeping in general, and "societies of intervention" as the result from such interventions (Bonacker et al. 2010). Simplified frames, such as "security first" or "democracy first" will not suffice in the future. The introduction of the rule of law and the creation of a wide political space and public sphere may be the best advice for designing future interventions. 


\section{References:}

Balfour, Rosa and Florian Bieber (2010). Bosnia fatigue, and how to deal with it. In: "EuropeanVoice.com", 22.04.2010. Available online at http://www.europeanvoice.com/article/imported/ bosnia-fatigue-and-how-to-deal-with-it/67775.aspx, accessed 06.02.2011.

Barnett, Michael (2006). Building a Republican Peace. Stabilizing States after War. In: International Security, vol. 30, no. 4, pp. 87-112.

Bassuener, Kurt and Bodo Weber (2010). Are we there yet? International impatience vs. a long-term strategy for a viable Bosnia. Policy Brief. Democratization Policy Council. Available online at http://democratizationpolicy.org/wp-content/uploads/2010/06/dpc_bosnia_policy_paper_are-we-there-yet1.pdf.

Bonacker, Thorsten, Michael Daxner, Jan H. Free and Christoph Zuercher (eds.) (2010). Interventionskultur. Zur Soziologie von Interventionsgesellschaften. Wiesbaden: VS Verlag für Sozialwissenschaften.

Chaigneau, Pascal (2010). Vers un monde post-américain. In: Pascal Chaigneau (ed.), Enjeux Diplomatiques et Strategiques 2010. Paris: Economica, pp. 7-13.

Chandler, David (1999). Faking Democracy After Dayton. Londong: Pluto Press.

Chesterman, Simon (2003). You, the People - The United Nations, Transitional Administration, and State-Building. New York: International Peace Academy.

Cox, Marcus (1998). Strategic Approaches to International Intervention in Bosnia and Herzegovina. Sarajevo: Centre for Applied Studies in International Negotiations (CASIN), Geneva. Available online at http://se1.isn.ch/serviceengine/ Files/ISN/102388/ipublicationdocument_singledocument/FF7DFCE0-13FC-4007-AD51-D83B934DD6CC/en/1998_10_Strategic_Approaches_to_International_Intervention.pdf, accessed 04.11.2009.

Crawford, Michael; Miscik, Jami (2010). The Rise of the Mezzanine Rulers. In: Foreign Affairs, vol. 89, no. 6, pp. 9.

Daxner, Michael (2003). Cohesive Policy for the Soft Sectors in South East Europe. Vienna: BMBWF.

Daxner, Michael (2010). Fifteen years of Peace-building Activities in the Western Balkans: Lessons Learned and Current Challenges. In: Connections - The Quartlerly Journal, vol. IX, no. 3, Summer 2010, pp. 63-74.

Dobbins, James, Seth G. Jones, Keith Crane, Christopher S. Civvis, Andrew Radin, F. Stephen Larrabee, Nora Bensahel, Brooke K. Stearns and Benjamin W. Goldsmith (2008). Europe's Role in Nation-Building. From the Balkans to the Congo. Santa Monica, CA: RAND.
Džihić, Vedran (2009). Ethnopolitik in Bosnien-Herzegowina: Staat und Gesellschaft in der Krise. Baden-Baden: Nomos.

Evenson, Kristie (2009). Bosnia and Herzegovina: Statebuilding and Democratization in the Time of Ethnic-Politics and International Oversight. In: Taiwan Journal of Democracy, vol. 5, no. 1, pp. 93-125.

Fagan, Adam (2010). Europe's Balkan Dilemma. Paths to Civil Society or State-Building? London: I.B. Tauris.

Gruber, Annie (2010). L'Élargissment der l'Union Européenne. In: Pascal Chaigneau (ed.), Enjeux Diplomatiques et Strategiques 2010. Paris: Economica, pp. 32-47.

Heider, Tobias (2010). Die Wirksamkeit von EPZ- und GASP-Krisenmanagement in Bosnien-Herzegowina 1991-1994. Doctoral Dissertation thesis at the OSI, Freie Universität.

ICG (2011). Bosnia: Europe's Time to Act. Europe Briefing. Sarajevo/Istanbul/Brussels: International Crisis Group. Available online at http://www.crisisgroup.org/ /media/Files/europe/ B59\%20Bosnia\%20--\%20Europes\%20Time\%20to\%20Act. ashx, accessed 12.01.2011.

Pfaff, William (2010). Manufacturing Insecurity. In: Foreign Affairs, vol. 89, no. 6, pp. 8 .

Starčević-Srkalović, Lejla (2010). The Democratization Process in Post-Dayton Bosnia and Herzegovina and the Role of the European Union. Baden-Baden: Nomos.

Stromseth, Jane; Wippman, David; Books, Rosa (2006). Can Might Make Rights? Building the Rule of Law after military Interventions. New York: Cambridge UP.

Tirak, Goran (2010). The Bosnian Hiatus: A Story of Misinterpretations. Policy Brief. Centre for European Policy Studies. Available online at http://ceps.eu/book/bosnian-hiatus-story-misinterpretations, accessed 07.02.2011.

Tolbert, David; Andrew Solomon (2006). United Nations Reform and Supporting the Rule of Law in Post-Conflict Societies. In: Harvard Human Rights Journal, vol. 19, no. 29.

Zaum, Dominik (2007). The Sovereignty Paradox. The Norms and Politics of International Statebuilding. Oxford: Oxford University Press.

Zürcher, Christoph, Sarah Riese and Nora Roehner (2009). External Democracy Promotion in Post-Conflict Zones. Evidence from Case Studies. In: Taiwan Journal of Democracy, vol. 5, no. 1, pp. 241-59. Available online at http://www.tfd.org.tw/english/tjd. php, accessed 09.03.2010. 